\title{
KONSTRUKSI KURIKULUM DAN PEMBELAJARAN TERPADU ANTARA PEN DIDIKAN AGAMA ISLAM (PAI) DAN PENDIDIKAN KEWARGANEGARAAN (PKn) DI SE KOLAH DASAR
}

\author{
Muhammad Turhan Yani, Rr. Nanik Setyowati, Derik Nur Islamiyah dan Galdh Pranggon
}

\begin{abstract}
Modd construction of amialum and integrated leaming between the Istamic Rdigiaus Eduration (PAI) and Civic Education (PKn) in dementary schools coiented to synergzethePAI and Civics teachersin designingintegrated learninga morecomprehensive and effetive whileimproing the pessonality of students for thefuture beable to reflet the intelectual potential and the potential for in attitude Basically, in theprocess of eduration and learning teaches are required to conduct a comprenensiveinmoations and effective to prevent saturation, both teachers and students. Concemed it, this rearch produres rearch that has been testedin threedenentaryschods(SD) in Surabaya in theformof construction of anintegrated amialumin a way to bringsamebasiccomptence of thesetwosubjets, then padkaged in an integrated leaming syllabus equipped, Leaming Implementation Plan, Instrutional Materials/ MoculeSimple, and theLemingGuide Keywords: CurriaulumandIntegratedleaming PAI, Civic
\end{abstract}

\section{Pendahuluan}

Dalam konteks pembelajaran ${ }^{1}$ di sekolah, guru Pendidikan Agama Islam (PAI) dan Pendidikan Kewarganegaraan (PKn) sebenarnya dapat bekerjasama secara komprehensif dan intensif yang dimulai dari menyusun visi, misi, dan tujuan pendidikan moral (pendidikan agama dan $\mathrm{PKn}$ ) secara bersama, karena dua mata pelajaran ini pada dasarnya memiliki visi dan misi pembentukan karakter yang sama, yaitu membentuk kepribadian anak didik² (siswa) agar menjadi pemeluk agama yang taat sekaligus warga negara yang baik ${ }^{3}$. Namun dalam realitasnya selama ini, para guru dari dua mata pelajaran tersebut, masih banyak yang berdiri sendiri sesuai dengan tugas masing-masing sebagai guru bidang studi. Indikator ini paling tidak dapat dilihat pada dua hal ${ }^{4}$. Petama, belum banyak atau bahkan belum ada konstruksi kurikulum dan pembelajaran di sekolah antara PAI dan PKn yang dikemas dalam pembelajaran dengan pendekatan terpadu. Kedua, belum terdapat buku/materi ajar terpadu antara PAI dan PKn yang dilengkapi Silabus, RPP, dan panduan pembelajaran. Asumsi peneliti, model konstruksi kurikulum dengan pendekatan terpadu ini merupakan upaya efektif dalam meningkatkan kepribadian siswa sekaligus menyinergikan peran guru PAI dan PKn, namun belum banyak dilakukan oleh para guru. Inilah yang menjadi urgensi pokok dari penelitian ini.

${ }^{*}$ Fakultas Ilmu Sosial Universitas Negeri Surabaya(UNESA).

${ }^{1}$ Istilah yang lebih tepat adalah pembelajaran (leming), bukan pengajaran. Konsep pembelajaran menekankan adanya interaksi timbal balik antara guru dan siswa (Lihat Mohamad Nur, Modd-modd Penbdajaran(Surabaya: Unesa University Press, 2005), 10.

${ }^{2}$ Menurut Ibn Miskawaih, tujuan dari mempelajari ilmu tidak semata karena ilmu itu sendiri, akan tetapi ada yang lebih substansial daripada itu, yaitu membentuk anak didik agar memiliki kepribadian yang baik (ahlaqal-karimah). ${ }^{3}$ Pemeluk agama yang taat dan warga negara yang baik (goodatizen) menurut para pakar merupakan modal yang sangat berharga dalam kehidupan beragama, berbangsa, dan bernegara.

${ }^{4}$ Hasil survey lapangan dan wawancara dengan beberapa guru sekolah dasar di Surabaya 12 A pril 2010. 
D alam K urikulum Tingkat Satuan Pendidikan (KTSP) yang disebut sebagai komplemen kurikulum berbasis kompetensi ${ }^{5}$, mata pelajaran PAI menempati posisi yang urgen. Karena mata pelajaran ini memberi spirit pada mata pelajaran lain. Kompetensi utama yang dituntut dalam mata pelajaran PAI tidak saja aspek kognitif, akan tetapi yang lebih penting adalah aspek afektif dan psikomotorik ${ }^{6}$. Oleh sebab itu, mata pelajaran PAI diharapkan menjadi spirit dan inspirasi bagi mata pelajaran lain dalam menumbuhkan karakter dan watak siswa.

Di sisi lain, mata pelajaran PKn juga diharapkan dapat menjadi pengikat untuk menyatukan visi bangsa Indonesia yang beragam dari segi agama, bahasa, usia, dan suku bangsa tentang budaya kebersamaan yang dapat mendukung tetap tegaknya negara kesatuan RI. Lebih-lebih dewasa ini negara kita dalam keadaan kurang stabil dan terancam disintegrasi. Oleh karena itu dalam penelitian ini dilakukan pengintegrasian antara Mata Pelajaran PAI dan PKn di SD dengan cara memberikan variasi perspektif terhadap beberapa kompetensi dasar yang memiliki kemiripan dari dua mata pelajaran tersebut.

D alam penelitian ini, model integrasi yang digunakan adalah IntegatedCumialumMode (ICM) yang dikembangkan oleh Robin Fogarty. Model ini merupakan kurikulum yang dikembangkan secara terpadu dengan pendekatan secara lintas disiplin ilmu untuk saling melengkapi pengetahuan. Dalam hal ini, ICM merupakan hasil pengayaan dari berbagai hasil ide mata pelajaran ${ }^{7}$. Model ini bukanlah model kurikulum yang mengembangkan berbagai mata pelajaran secara terpisah melainkan diintegrasikan satu sama yang lain, misalnya antara materi PAI dan PKn.

Model ini mempunyai keuntungan yaitu kemudahan belajar yang mengarah pada keterkaitan antara berbagai disiplin ilmu. ICM dapat membangun pemahaman lintas mata pelajaran dan dapat mengapresiasikan pada tingkat pengetahuan yang lebih tinggi. Model integrasi ini juga mampu memberikan motivasi kepada siswa sehingga siswa dapat belajar secara menyenangkan ${ }^{8}$.

Ada beberapa kendala dalam melaksanakan ICM Model ini sulit untuk dilaksanakan sepenuhnya dengan memakai disiplin ilmu yang berbeda. Model pembelajaran ini membutuhkan tingkat keahlian yang sangat tinggi sehingga dibutuhkan guru-guru yang mempunyai kompetensi profesional yang sangat tinggi pula. Model kurikulum ini memerlukan tim antar-departemen dengan perencanaan waktu mengajar yang sama sehingga antara materi mata pelajaran yang satu dengan yang lain ada keterkaitan satu dengan yang lainnya. Model kurikulum ini hanya dapat digunakan jika terdapat relevansi materi antara mata pelajaran yang satu dengan yang lain ${ }^{9}$.

D engan demikian, dalam penelitian ini diajukan pertanyaan sebagai berikut; Bagaimana model konstruksi kurikulum dan pembelajaran terpadu antara Pendidikan Agama Islam (PAI) dan Pendidikan Kewarganegaraan (PKn) di sekolah dasar?. Penelitian ini bertujuan untuk memetakan kompetensi dasar dalam kurikulum SD yang dapat dikembangkan dengan perspektif PAI dan PKn secara lintas disiplin, dan sekaligus mengembangkan model Silabus,

\footnotetext{
${ }^{5}$ D epdiknas, KunikulumTingkat Satuan Pendidikan(KTSP) (Jakarta : 2006), 5.

${ }^{6}$ M Turhan Yani, Dialdktika SeputarPendidikan(Surabaya: Unesa University Press, 2006), 15.

${ }^{7}$ Robin Fogarty, HowToIntegrateTheCumiala(Palatine: Illinois, 1991), 95.

${ }^{8}$ Ibid., 96.

${ }^{9}$ Ibid., 97.
} 
Rencana Pelaksanaan Pembelajaran (RPP), dan materi ajar terpadu antara Mata Pelajaran PAI dan PKn di SD sebagai upaya peningkatan sinergitas guru dan kepribadian siswa. Adapun manfaat penelitian ini dapat memberikan inovasi bagi guru PAI dan PKn dalam hal konstruksi kurikulum terpadu, dan juga dapat memberikan peluang bagi guru PAI dan PKn untuk bersinergi dalam proses pembelajaran.

\section{Metode Penelitian}

O byek dalam penelitian ini adalah dokumen kurikulum PAI dan PKn dalam Kurikulum Tingkat Satuan Pendidikan (KTSP) di SD ${ }^{10}$. A dapun subyek penelitian ini adalah guru PAI dan PKn di SD N Menanggal 601 Surabaya, SD N Ketintang Barat I Surabaya, SD N Babatan IV Surabaya. Setiap sekolah melibatkan 2 orang guru untuk masing-masing mata pelajaran PAI dan PKn. Para guru yang dimaksud dalam penelitian ini adalah D rs. Abu, guru agama Islam kelas VI dan D ra. K hatijah, guru PKn kelas V (keduanya berasal dari SD N Menanggal 601 Surabaya), selanjutnya adalah D ra. Islamiyah guru agama Islam kelas VI dan D ra. Ruti guru PKn kelas V (keduanya berasal dari SD N Ketintang I Surabaya), sedangkan dua guru yang terakhir adalah D rs. D uladi guru agama Islam kelas VI dan D ra. Minsyariyah guru PKn kelas V (keduanya berasal dari SD N Babatan IV Surabaya).

Teknik wawancara, observasi, dan diskusi kelompok digunakan dalam tahap-tahap pengumpulan data selama kegiatan penelitian ini berlangsung (lihat tabel). Secara rinci penelitian ini dimulai dari fase diagnostik, yaitu mengidentifikasi dengan jalan melakukan telaah terhadap kurikulum KTSP untuk Mapel PAI dan PKn di SD, kemudian dilakukan pengidentifikasian terhadap standar kompetensi (SK) dan kompetensi dasar (KD) $)^{11}$ yang dapat dipertemukan dari dua mata pelajaran tersebut, selanjutnya dipetakan dan dilakukan perumusan model konstruksi kurikulum dan pembelajaran dengan pendekatan terpadu yang meliputi, Silabus dan Rencana Pelaksanaan Pembelajaran (RPP) terpadu antara Mata Pelajaran PAI dan PKn, selanjutnya membuat materi ajar terpadu antara Mata Pelajaran PAI dan PKn di SD yang dilengkapi panduan pembelajaran ${ }^{12}$. Adapun rancangan penelitian dapat dilihat di tabel 1 pada halaman 184.

Analisis data penelitian ini dilakukan dengan cara menggunakan analisis kualitatif ${ }^{13}$ dengan berdasar pada narasi berpikir logis yang diawali dengan telaah kurikulum KTSP untuk mata Pelajaran PAI dan PKn di SD, survei, dan pand grap disassion ${ }^{14}$, selanjutnya disusun pemetaannya, kemudian dianalisis menggunakan analisis kualitatif dengan berdasar pada studi empiris dan berpikir logis mengenai konstruksi kurikulum PAI dan PKn di SD dengan pendekatan terpadu, kemudian didiskusikan, selanjutnya dirumuskan model pengembangannya yang diawali dengan uji coba.

\footnotetext{
${ }^{10}$ D epdiknas, KunikulumKTSP untuk Mapd PendidkanAgamaIsamdanPendidikanKenarganegaraan di SD (Jakarta: Depdiknas, 2006).

${ }^{11}$ Depdiknas, DdkumenKTSP untuk Mapd PAI danPKn(Jakarta : D epdiknas, 2006), 5.

${ }^{12}$ Perangkat pembelajaran di antaranya meliputi Silabus, RPP, materi ajar, dan panduan pembelajaran.

${ }^{13}$ Basrowi Sudikin, MetodePenditian Kualitatif Pespoktif Mikro(Jakarta: Insan Cendekia, 2002).

${ }^{14}$ Pand groupdisassiondimaksudkan untuk mencari masukan dari para ahli terkait dengan fokus penelitian.
} 
Tabel 1 : Rancangan Penelitian

\begin{tabular}{|c|c|c|c|c|}
\hline KEG IATAN & TUJUAN & METODE & SA SARAN & HASIL \\
\hline $\begin{array}{l}\text { Telaah kuri- } \\
\text { kulum KTSP } \\
\text { untuk Mapel } \\
\text { PAI \& PKn } \\
\text { di SD }\end{array}$ & $\begin{array}{l}\text { Mengidentifikasi } \\
\text { kompetensi dasar } \\
\text { Mapel PA I dan } \\
\text { PKn } \\
\text { > Mengidentifikasi } \\
\text { kompetensi dasar } \\
\text { yang dapat diper- } \\
\text { temukan }\end{array}$ & $\begin{array}{l}\text { Studi pusta- } \\
\text { ka dan telaah } \\
\text { mendalam }\end{array}$ & $\begin{array}{l}\text { D o k u m en } \\
\text { kurikulum } \\
\text { KTSP }\end{array}$ & $\begin{array}{l}\text { Ditemukan kompetensi } \\
\text { dasar yang memiliki } \\
\text { kesamaan dari dua } \\
\text { Mapel (PAI dan PKn). }\end{array}$ \\
\hline$>$ Pemetaan & $\begin{array}{l}\text { Memetakan kom- } \\
\text { petensi dasar yang } \\
\text { memiliki kesa- } \\
\text { maan di dalam } \\
\text { kurikulum PAI) } \\
\text { dan PKn di SD } \\
\text { M en gan alis is } \\
\text { kompetensi dasar } \\
\text { dari dua mata } \\
\text { pelajaran (PAI dan } \\
\text { PKn) untuk selan- } \\
\text { jutnya diintegra- } \\
\text { sikan }\end{array}$ & $\begin{array}{l}\text { Wawancara } \\
\text { dengan para } \\
\text { guru dan } \\
\text { Foaus Group } \\
\text { Disassion }\end{array}$ & $\begin{array}{l}\text { D o k u m e n } \\
\text { kurikul um } \\
\text { KTSP. }\end{array}$ & $\begin{array}{l}\text { Pemetaan dan analisis } \\
\text { untuk konstruksi kuri- } \\
\text { kulum terpadu dari dua } \\
\text { Mapel (PAI dan PKn). }\end{array}$ \\
\hline$>$ Perumusan & $\begin{array}{l}\text { M eru muskan } \\
\text { model Silabi dan } \\
\text { Rencana Pelak- } \\
\text { sanaan Pembela- } \\
\text { jaran (RPP) de- } \\
\text { ngan pendekatan } \\
\text { terpadu an-tara } \\
\text { Mata Pelaja-ran } \\
\text { PAI dan PKn di } \\
\text { SD. }\end{array}$ & $\begin{array}{l}\text { T e l a a } h \\
\text { mendalam } \\
\text { dan foaus } \\
\text { gaip }\end{array}$ & Para guru & $\begin{array}{l}\text { Perumusan model } \\
\text { konstruksi kurikulum } \\
\text { dengan pendekatan } \\
\text { terpadu (PAI dan } \\
\text { PKn)Masukan dari hasil } \\
\text { uji coba di SD. }\end{array}$ \\
\hline $\begin{array}{l}\text { P eng em - } \\
\text { bangan }\end{array}$ & $\begin{array}{l}\text { Uji Coba materi } \\
\text { yang dikembang- } \\
\text { kan dengan per- } \\
\text { spektif PAI dan } \\
\text { PKn di SD }\end{array}$ & $\begin{array}{l}\text { Discussion } \\
\text { (para } \\
\text { dan } \\
\text { peneliti) }\end{array}$ & Para guru & $\begin{array}{l}\text { Silabus, RPP, dan materi } \\
\text { ajar PAI dan PKn } \\
\text { terintegrasi }\end{array}$ \\
\hline $\begin{array}{l}\text { Hasil akhir } \\
\text { yang sudah } \\
\text { d ir e v i s i } \\
\text { (finalisasi) }\end{array}$ & $\begin{array}{l}\text { Mengembangkan } \\
\text { Silabus, RPP, dan } \\
\text { membuat materi } \\
\text { ajar terpadu antara } \\
\text { Mata Pelajaran } \\
\text { PAI dan PKn di } \\
\text { SD yang dileng- } \\
\text { kapi panduan } \\
\text { pembelajaran }\end{array}$ & $\begin{array}{l}\text { Pand group } \\
\text { dsaussion }\end{array}$ & Para guru & \\
\hline
\end{tabular}




\section{Hasil Penelitian}

Studi pendahuluan yang telah dilakukan dalam penelitian ini melalui dua kegiatan. Petama, studi literatur dengan cara menelaah kurikulum KTSP pada mata pelajaran PAI dan PKn di SD. Studi literatur ini penting dilakukan sebagai dasar pemahaman konsep konstruksi kurikulum dua mata pelajaran dengan pendekatan terpadu. Keelua, studi empiris yang dilakukan di lapangan (survei ke sekolah) terkait dengan konstruksi kurikulum dan pembelajaran PAI dan PKn di SD dengan pendekatan terpadu ${ }^{15}$ ternyata belum dilakukan oleh guru PAI dan PKn di SD N Menanggal 601 Surabaya, SD N Ketintang Barat I Surabaya, dan SD N Babatan IV Surabaya.

Berdasarkan kajian yang telah dilakukan terhadap kurikulum PAI SD kelas VI dan PKn kelas $\mathrm{V}^{16}$, dapat dikemukakan bahwa terdapat kompetensi dasar PAI kelas VI yang dapat diintegrasikan dengan PKn dengan cara memberikan perspektif ke-PKn-an. D emikian pula kompetensi dasar PKn kelas V juga dapat diintegrasikan dengan perspektif ke-PAI-an.

Secara lebih detail kompetensi dasar yang dapat dikembangkan dengan model integrasi dengan perspektif PKn terdapat pada kelas 6 semester 1 pada Standar Kompetensi (SK) 4 (tentang akhlaq), yaitu menghindari perilaku tercela dengan Kompetensi Dasar (KD) 4.1 menghindari perilaku dengki, dan KD 4.2 menghindari perilaku sombong. Sedangkan untuk kurikulum KTSP PKn di SD yang dapat dikembangkan dengan perspektif PAI terdapat pada kelas 5 semester 1 pada SK 1 memahami pentingnya Negara Kesatuan Republik Indonesia (NKRI) dengan KD 1.3 menunjukkan contoh-contoh perilaku dalam menjaga keutuhan Negara Kesatuan Republik Indonesia ${ }^{17}$.

Dipilihnya SK dan KD dua mata pelajaran tersebut didasarkan pada pertimbangan sebagai berikut. (1) SK dan KD tersebut terdapat pada semester 1 yang waktunya sesuai dengan program penelitian, (2) SK dan KD tersebut cocok untuk dikembangkan dengan perspektif PAI dan PKn. Sebenarnya SK dan KD PAI untuk kelas 4 ada yang cocok untuk dipilih namun SK dan KD tersebut terdapat pada semester 2 yang tentunya tidak sesuai dengan waktu penelitian ini dilakukan.

Setelah dilakukan pengidentifikasian dan pemetaan terhadap standar kompetensi dan kompetensi dasar, maka langkah selanjutnya yang dikembangkan adalah kajian mendalam dan diskusi dengan tim terkait dengan model pengintegrasian. Konsep integrasi yang dimaksud dalam penelitian ini mengacu pada model integrasi menurut Fogarty, yaitu memberi perspektif PKn bagi kompetensi dasar PAI dan juga memberi perspektif PAI bagi kompetensi dasar PKn.

Adapun Integated arrialum modd ${ }^{18}$ antara mata pelajaran Pendidikan Agama Islam dan Pendidikan Kewarganegaraan dapat digambarkan pada diagran 1 dan 2 di halaman 186.

Sebelum membuat bahan/materi ajar, tim peneliti terlebih dahulu membuat silabus dan rencana pelaksanaan pembelajaran (RPP) terpadu yang sudah diberi perspektif PAI bagi kompetensi dasar PKn dan perspektif PKn bagi kompetensi dasar PAI ${ }^{19}$.

\footnotetext{
${ }^{15}$ Pendekatan terpadu (Integraed Approach) yang dimaksud dalam penelitian ini mengacu pada model terpadu menurut Robin Fogarty.

${ }^{16}$ D okumen KTSP 2006.

${ }^{17}$ Hasil telaah tim peneliti terrhadap kurikulum PAI dan PKn SD.

${ }^{18}$ Fogarty, HowToIntegrate, 95.

${ }^{19}$ Silabus dan RPP dibuat sebagai suatu pijakan dalam pengembangan bahan ajar dan pembelajaran di kelas.
} 


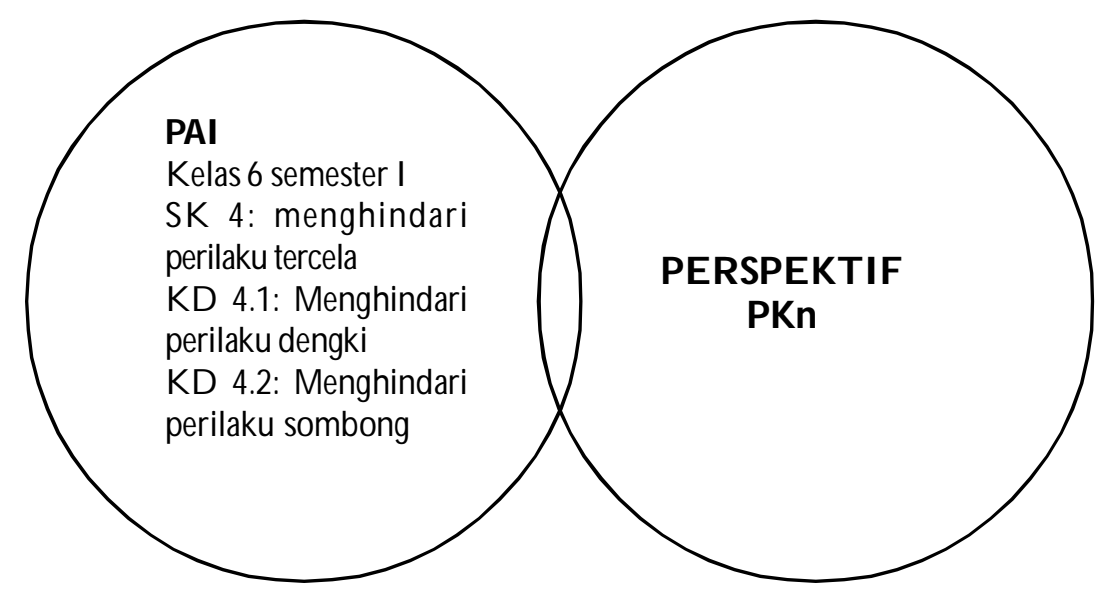

\section{Diagram 1. Integrasi PAI dan PKn}

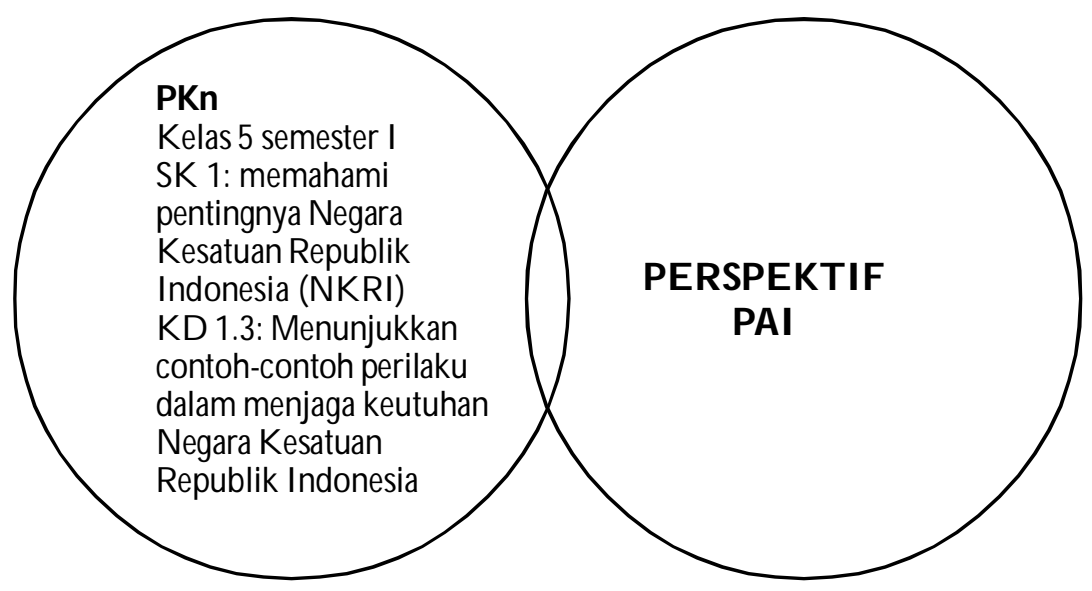

\section{Diagram 2. Integrasi PKn dan PAI}

Setelah Silabi, RPP, dan bahan/materi ajar (modul) selesai disusun oleh tim peneliti, maka langkah selanjutnya adalah mengundang para guru pengampu bidang studi tersebut untuk mendiskusikan bahan penelitian. Para guru yang dimaksud dalam penelitian ini berasal dari tiga sekolah, yaitu SD N Menanggal 601 Surabaya, SD N Ketintang 1 Surabaya, dan SD N Babatan IV Surabaya. Masing-masing sekolah mengirim 1 orang guru PAI dan PKn. Jadi jumlah keseluruhan ada 6 orang guru.

Para guru yang menjadi groupdsassiondalam penelitian ini diundang secara bersamaan ke Universitas Negeri Surabaya (UNESA) untuk mendiskusikan bahan penelitian yang telah dirancang oleh tim peneliti. D ari proses diskusi beberapa kali tersebut ada beberapa masukan yang disampaikan oleh para guru, yaitu model integrasi ini perlu disesuaikan dengan tingkat kemampuan siswa SD, baik dalam hal materi ajar maupun bahasanya, dan juga pedoman pelaksanaannya. ${ }^{20} \mathrm{D}$ alam proses diskusi, para guru dari ketiga sekolah tersebut merasa ada sesuatu yang baru dalam penelitian ini, yakni mereka merasa ada terobosan inovatif dalam

\footnotetext{
${ }^{20}$ Abu dan I slamiyah (Guru PAI) dan K hadijah (Guru PKn), Wamancara, Surabaya, 10 O ktober 2010.
} 
kurikulum dan pembelajaran PAI dan PKn SD melalui model integrasi. ${ }^{21}$

Diskusi dengan para guru untuk membahas bahan penelitian ini berlangsung dengan hangat dan penuh keakraban dan para guru merasa senang dengan adanya terobosan inovatif dalam penelitian ini. Materi diskusi meliputi bagian-bagian sebagai berikut. (1) Silabus, (2) RPP, (3) Bahan/ Materi ajar (modul), (4) rencana uji coba di kelas, dan (5) panduan pembelajaran. ${ }^{22}$

Selanjutnya untuk dapat memahami secara maksimal terhadap rancangan dan bahan penelitian ini sebelum diujicobakan di kelas, para guru diberi kesempatan 1 minggu untuk mencermati dan memahami bahan penelitian di rumah agar mereka dapat mempersiapkan dengan baik pada saat uji coba di kelas. Setelah pendalaman produk penelitian selesai dipahami oleh para guru dari tiga sekolah yang menjadi tempat penelitian ini, selanjutnya dilakukan uji coba di sekolah masing-masing dengan didampingi oleh tim peneliti. ${ }^{23}$

Sebelum dilakukan uji coba, tim peneliti terlebih dahulu memaparkan beberapa hal sebagai berikut. (1) arti pentingnya penelitian ini. ${ }^{24}$ Penelitian ini penting dilakukan sebagai upaya untuk menyinergikan peran guru PAI dan PKn dan juga untuk membentuk karakter siswa secara komprehensif dan efektif yang dilakukan secara kolaboratif antara guru PAI dan PKn, (2) produk penelitian. Penelitian ini akan menghasilkan gagasan dan terobosan inovatif dalam konstruksi kurikulum dan pembelajaran PAI dan PKn. Setelah dua hal tersebut disampaikan, para guru memberikan tanggapan dan masukan-masukan untuk selanjutnya dilakukan uji coba di sekolah. Setelah uji coba produk penelitian selesai, diskusi/ pertemuan berikutnya adalah membahas hasil uji coba antara tim peneliti dan para guru. Pertemuan tersebut dimaksudkan untuk mendiskusikan produk penelitian terkait dengan kesesuaian dan keefektifan dalam proses pembelajaran di kelas. ${ }^{25}$

D alam proses uji coba produk penelitian, tim peneliti juga memberikan catatan-catatan terhadap uji coba yang dilakukan oleh para guru. Catatan tersebut berupa kecakapan guru dalam proses uji coba dan tingkat kemampuan siswa kelas VI B dan kelas V B dari tiga sekolah. Hasil catatan ${ }^{26}$ tim peneliti menunjukkan bahwa guru PAI dan PKn SD N Menanggal 601 Surabaya beserta siswa kelas VI B dan kelas V B yang menjadi sasaran uji coba termasuk kategori memiliki kecakapan baik dalam membelajarkan produk penelitian ini kepada siswa. Demikian juga siswa kelas VI B dan kelas V B di sekolah ini juga memiliki kemampuan yang baik pula. Sedangkan guru PAI di SDN Ketintang I Surabaya dalam membelajarkan produk penelitian ini kepada siswa kelas VI B dan kelas V B memiliki kecakapan baik, sementara itu untuk guru PKn di sekolah ini memiliki kecakapan sedang. D emikian juga siswa di sekolah ini memiliki tingkat kemampuan yang sedang. Sementara itu guru PAI dan PKn SD N Babatan IV Surabaya dalam membelajarkan produk penelitian ini kepada siswa

\footnotetext{
${ }^{21}$ Menurut para guru yang menjadi subjek dalam penelitian ini, kurikulum dan pembelajaran PAI dan PKn selama ini berdiri sendiri, belum dilakukan pengintegrasian semacam ini.

${ }_{22}$ Diskusi pertama dilaksanakan pada tanggal 19 Agustus 2010 di ruang perpustakaan Jurusan PMP-Kn FIS UNESA.

${ }^{23}$ Uji coba di sekolah dilakukan mulai tanggal 26 A gustus-02 September 2010.

${ }^{24} \mathrm{D}$ alam istilah lain sering disebut dengan signifikansi penelitian sebagaimana sering digunakan oleh Amin Abdullah.

${ }^{25}$ D iskusi kedua dilaksanakan pada tanggal 30 September di ruang perpustakaan Jurusan PMP-Kn FIS UNE SA.

${ }^{26} \mathrm{H}$ asil observasi di tiga sekolah yang menjadi tempat penelitian ini.
} 
memiliki kecakapan yang sedang untuk guru PKn dan kecakapan yang rendah untuk guru PAI. D an, siswa kelas VI B dan kelas V B sekolah tersebut tingkat kemampuannya juga termasuk rendah.

Terkait dengan kecakapan para guru yang membelajarkan produk penelitian ini menunjukkan hasil berbeda, beberapa di antaranya juga bergantung pada tingkat kemampuan siswa dan fasilitas pendukung yang berbeda di samping faktor kompetensi guru sendiri. ${ }^{27}$ Indikator kecakapan guru yang dimaksud di sini adalah kemampuan menjelaskan materi secara jelas sesuai dengan Silabus, RPP, materi ajar/ modul, mengusai kelas, menggunakan strategi pembelajaran yang menarik, menggunakan media yang menarik (seperti yang dilakukan oleh Ibu Khadijah, guru PKn SD N Menanggal 601 Surabaya yang menggunakan LCD ), dan dapat menstimulus siswa.

Para guru mengatakan tidak ada kendala berarti dalam uji coba produk penelitian ini, hanya ada sedikit yang menurut sebagian guru menjadi kendala kecil, yaitu membelajarkan materi PKn dalam perspektif agama Islam pada kelas yang beberapa siswanya ada yang nonmuslim dan juga minimnya pengetahuan guru dalam hal agama sebagaimana yang dikemukakan oleh Dra. Ruti, ${ }^{28}$ guru PKn SD N Ketintang I Surabaya. Namun setelah tim peneliti menco ba menjelaskan kepada para guru, bahwa modul PKn SD yang diberi perspektif agama Islam dalam penelitian ini sama sekali tidak terkait dengan masalah ritual-ibadah, akan tetapi terkait dengan masalah tanggung jawab sosial sebagai warga negara yang baik. D alam kaitan ini perspektif agama Islam diberikan untuk menegaskan bahwa dalam ajaran Islam juga diajarkan tentang masalah tersebut, ${ }^{29}$ bahkan dalam semua agama juga demikian, sehingga dengan demikian tidak menjadi masalah membelajarkan materi PKn pada kelas yang beberapa siswanya ada yang non muslim. Setelah tim peneliti menjelaskan demikian, para guru akhirnya mengerti.

Adapun terkait dengan adanya guru yang pengetahuan agamanya minim, menurut tim peneliti sesungguhnya tidak menjadi masalah. Sekiranya memang kemampuan guru dalam hal agama Islam minim, maka perspektif agama Islam pada materi PKn SD hanya bersifat menegaskan saja tanpa mengutip dalil atau dasar al-Q ur'an dan hạdithnya. Akan tetapi bagi guru PKn yang memiliki pengetahuan agama dengan baik dapat menambahkan penjelasan dalil atau dasarnya. Pada sisi lain guru agama Islam SD juga perlu menambah wawasan terkait dengan perspektif PKn dalam mata pelajaran PAI, namun bagi guru agama Islam SD yang menjadi subyek penelitian ini, wawasan tentang ke-PKn-an dalam mata pelajaran PAI SD telah diberikan dengan baik, dan sikap nasionalisme mereka juga baik.

Selanjutnya setelah melalui beberapa diskusi, tim peneliti juga mewancarai para guru terkait dengan apa yang perlu diperbaiki lagi terkait dengan produk penelitian ini, para guru menjawab pendidikan karakter perlu dimasukkan. ${ }^{30}$ Setelah tim mencermati masukan tersebut, ternyata pendidikan karakter sudah indudedalam mata pelajaran PAI dan PKn. Setelah proses

\footnotetext{
${ }^{27}$ D ari tiga sekolah, guru PAI dan PKn SD N Menanggal 601 Surabaya lebih cakap dalam membelajarkan produk penelitian ini.

${ }^{28}$ Ruti (G uru PKn), Wanancara, Surabaya, 7 September 2010.

${ }^{29} \mathrm{Ajaran}$ Islam mengajarkan tentang tanggung jawab sosial kepada umatnya, di antaranya tentang cinta tanah air dan menjaga keutuhan/ persatuan dan kesatuan.

${ }^{30}$ D ulhadi (Guru PAI) dan Minsyariyah (G uru PKn), Wavancara, Surabaya, 120 ktober 2010.
} 
tersebut selanjutnya dilakukan finalisasi produk penelitian. ${ }^{31}$

\section{Pembahasan}

D engan dipetakannya Kompetensi D asar (KD) atau topik tertentu dalam kurikulum PAI dan PKn SD maka jelaslah terdapat KD atau topik tertentu yang dapat ditinjau dari berbagai disiplin ilmu, misalnya dalam penelitian ini adalah materi PAI kelas VI SD pada KD Menghindari Perilaku Tercela (aspek akhlaq) dapat ditinjau dari perspektif ke-PKn-an, yakni agar menjadi warga negara yang baik dalam kehidupan berbangsa dan bernegara, maka setiap warga negara harus menghindari perilaku tercela seperti iri, dengki, benci, dan lainlain. ${ }^{32}$

D emikian pula materi PKn kelas V SD pada KD Menjaga Keutuhan NKRI juga dapat ditinjau dari perspektif agama Islam, yakni agama Islam mengajarkan bahwa menjaga keutuhan NKRI merupakan suatu kewajiban bagi setiap warga negara dengan cara memelihara persatuan dan kesatuan, mencintai tanah air, dan lain sebagainya. ${ }^{33}$

Mengacu pada model integrasi yang dikembangkan oleh Robin Fogarty, ${ }^{34}$ integrasi yang seperti itulah yang sesuai dengan karakteristik mata pelajaran PAI dan PKn pada KD yang telah dikemukakan di atas. Oleh karena itu, para guru PAI dan PKn, hendaknya bersinergi untuk mengembangkan KD tersebut dengan perspektif ke-PAI-an dan ke-PKnan, khususnya pada beberapa KD yang telah dipetakan untuk diintegrasikan agar terwujud konstruksi kurikulum yang terpadu (integrasi), kemudian dilanjutkan dengan pembelajaran yang terpadu pula dalam bentuk team teading ${ }^{35}$ atau minimal materi pembelajaran/ KD tertentu dalam kurikulum PAI dan PKn telah didiskusikan bersama, kemudian implementasinya sendiri-sendiri dengan tetap mengacu konsep integrasi antara PAI dan PKn.

Paradigma modern yang perlu dikembangkan oleh para guru PAI dan PKn adalah bahwa mereka sejatinya dituntut untuk selalu bersinergi dalam konteks pembentukan karakter anak didik. Sebagai upaya untuk mewujudkan capaian tersebut, guru PAI dan PKn dapat memulai dari penyamaan visi, mendiskusikan KD tertentu secara lintas disiplin antara PAI dan PKn, sampai pada proses pembelajaranya. D engan upaya seperti itu maka akan terwujud sinergitas guru dan efektifitas pembentukan kepribadian atau karakter anak didik. Ibarat membangun sebuah rumah, akan cepat selesai jika rumah tersebut dibangun berdua dibandingkan dengan dibangun sendiri.

Temuan penelitian terkait dengan pengintegrasian KD tertentu dalam penelitian ini, misalnya KD Menghindari Perilaku Tercela pada kurikulum PAI SD kelas VI dapat dikembangkan dengan perspektif PKn dan KD Menjaga Keutuhan NKRI pada kurikulum PKn SD kelas V dapat dikembangkan dengan perspektif PAI penting sekali dikembangkan pada penelitian berikutnya. Produk integrasi dalam lintas disiplin ilmu, perlu dimulai dari

\footnotetext{
${ }^{31}$ Finalisasi produk penelitian dilakukan pada tanggal 150 ktober melalui diskusi antara tim peneliti dan para guru yag menjadi subyek dalam penelitian ini.

${ }^{32}$ Untuk lebih rinci mengenai hasil penelitian ini dapat dilihat pada produk penelitian ini dalam bentuk Materi Ajar Terpadu PAI-PKn dalam bagian tersendir, tidak menjadi bagian dari artikel.

${ }^{33}$ Ibid.

${ }^{34}$ Fogarty, HowToIntegrated 95.

${ }^{35}$ Sebuah pembelajaran yang dilakukan secara bersama oleh guru pada saat mengajar. Istilah yang populer akhirakhir ini disebut dengan LessonStudy.
} 
pemetaan SK dan KD terlebih dahulu, kemudian dipertemukan/dipadukan, selanjutnya dilakukan penyusunan Silabi integrasi, RPP integrasi, materi ajar/modul integrasi, dan pembelajaran integrasi dalam bentuk teamteachingsebagaimana yang tercermin dalam produk penelitian ini. Jika pelaksanaan pembelajaran tidak bisa dilakukan bersama oleh guru maka minimal bahan ajar sudah didiskusikan dengan guru temteaching

Menurut Fogarty, integrated arrialum modd ini mempunyai keuntungan, yaitu kemudahan belajar yang mengarah pada keterkaitan antara berbagai disiplin ilmu. Integated arrialum modd dapat membangun pemahaman lintas mata pelajaran dan dapat mengapresiasikan pada tingkat pengetahuan yang lebih tinggi. Model integrasi inijuga mampu memberikan motivasi kepada siswa sehingga siswa dapat belajar secara menyenangkan ${ }^{36}$.

Ada beberapa kendala dalam melaksanakan model ini. Model ini sulit untuk dilaksanakan sepenuhnya dengan memakai disiplin ilmu yang berbeda. Model pembelajaran ini membutuhkan tingkat keahlian yang sangat tinggi sehingga dibutuhkan guru-guru yang mempunyai kompetensi profesional yang sangat tinggi pula. ${ }^{37} \mathrm{D}$ alam konteks penelitian ini, model yang dikembangkan ini tidak sulit diterapkan karena bidang studi PAI dan PKn memiliki visi yang sama, yaitu membangun karakter anak didik melalui materi yang bisa disinergikan dan perilaku konkrit dalam kehidupan sehari-hari, misalnya tanggung jawab sebagai pemeluk agama sekaligus warga negara yang baik merupakan harapan suatu bangsa. Untuk bisa mencapai itu, bidang studi PAI dan PKn dapat menyinergikan melalui proses pendidikan dan pembelajaran, khususnya di sekolah.

D alam paradigma pendidikan Islam sebagaimana yang dikemukakan oleh Ibn Sina (980-1039 M) yang oleh dunia Barat dikenal dengan Avicenma dinyatakan bahwa tujuan pendidikan harus diarahkan pada pengembangan seluruh potensi yang dimiliki seseorang ke arah perkembangannya yang sempurna, yaitu perkembangan fisik, intelektual, dan budi pekerti. ${ }^{38}$ O rientasi PAI dan PKn pada dasarnya mengarah pada pendidikan yang bercorak moral-religius seperti yang tersirat dalam konsep tádib3 yaitu memadukan ilmu dan amal.

D engan demikian, berbagai bidang ilmu yang diajarkan dalam proses pendidikan seharusnya tidak diajarkan semata-mata karena ilmu itu sendiri atau tujuan akademik semata, akan tetapi juga karena tujuan lain yang lebih substansial, yaitu akhlaq atau kepribadian yang mulia. ${ }^{40}$ D engan kata lain, setiap bidang ilmu membawa misi akhlaq mulia. Melalui pendekatan terpadu seperti tersusunnya silabus, RPP, dan materi ajar/ modul yang dilengkapi panduan pembelajaran di SD ini diharapkan akan dapat meningkatkan kepribadian siswa sekaligus menyinergikan peran guru PAI dan PKn secara komprehensif dan efektif dalam proses pembelajaran.

Selanjutnya terkait dengan implementasi produk penelitian ini dalam pembelajaran di tiga sekolah yang menjadi tempat uji coba dapat dikemukakan bahwa sekolah yang tingkat kualitas akademiknya berbeda, lebih khusus lagi perbedaan kualitas atau kompetensi guru dan siswa akan menghasilkan kualitas pembelajaran yang berbeda pula. Fakta ini dapat

${ }^{36}$ Fogarty, HowToIntegrate, 97.

${ }^{37}$ Ibid., 96.

${ }^{38}$ Muhammad Naquib Al-Attas, The Concept of Eduration in Isam: A Framenork for an Islamic Philoshophy of Eduration, terj. Haidar Baqir (Bandung : Mizan, 1994), 50.

${ }^{39} \mathrm{~A}$ budin Nata, Perikiran ParaTdkdhPenddikan Idam(Jakarta: UIN, 2000), 25.

${ }^{40} \mathrm{Pandangan}$ Ibn Miskawaih 
dilihat dari catatan tim peneliti, yakni produk penelitian ini tampak lebih mengena dan efektif ketika diterapkan di SD N Menanggal 601 Surabaya dan SD N Ketintang I Surabaya yang masing-masing kategori sekolah dengan kualitas baik dan kualitas menengah atau sedang (termasuk guru dan siswanya), jika dibandingkan dengan sekolah yang kualitasnya rendah seperti SD N Babatan IV Surabaya.

Namun demikian, karena produk penelitian ini didesain untuk siswa SD, maka walaupun sekolah tersebut kualitas siswanya kategori rendah, produk penelitian ini tetap dapat disesuaikan dengan tingkat kemampuan siswa karena materi ajar/ modul yang disusun telah disesuaikan dengan tingkat kemampuan siswa SD, baik dari sisi substansi materi maupun bahasanya.

Berdasarkan catatan tim peneliti, ${ }^{41}$ strategi yang digunakan guru dalam membelajarkan materi ajar kepada siswa sangat menentukan daya tangkap dan kemenarikan siswa di samping juga karena kemampuan siswa dan media yang digunakan. Sebagai contoh, ketika guru menggunakan media LCD, bermain peran, dan menampilkan contoh-contoh gambar visual terkait dengan materi yang dibahas akan tampak lebih menarik dan membantu siswa SD untuk lebih cepat mengerti jika dibandingkan menggunakan cara konvensional seperti ceramah. ${ }^{42}$ Oleh karena itu di sinilah guru dituntut untuk melakukan inovasi pembelajaran, baik dalam hal mengemas materi, media, maupun strategi yang digunakan seperti dalam produk penelitian ini.

\section{Penutup}

Simpulan D ari uraian yang telah dikemukakan dapat ditarik simpulan bahwa dalam kurikulum SD, terdapat kompetensi dasar (KD) Pendidikan Agama Islam (PAI) dan Pendidikan Kewarganegaraan ( $\mathrm{PKn}$ ) yang dapat dipertemukan dengan model integrasi. Model integrasi yang dimaksud dalam penelitian ini adalah memberi perspektif PKn bagi KD PAI dan sebaliknya memberi perspektif PAI bagi KD PKn. Model konstruksi kurikulum dan pembelajaran terpadu dalam penelitian ini berupa Silabus, RPP, dan materi ajar/ modul PAI dan PKn. D engan kata lain bernama Silabus, RPP, dan Modul Integrasi.

Saran Produk penelitian ini hendaknya dapat menjadi inspirasi untuk dikembangkan lebih lanjut. Oleh karena itu para pelaksana pendidikan, khususnya guru PAI dan PKn dapat menindaklanjuti produk penelitian ini dengan cara memetakan kompetensi dasar dalam kurikulum PAI dan PKn yang sekiranya dapat diintegrasikan.

\section{Daftar Rujukan}

Attas (al), Muhammad Naquib. TheConcept of Education in Isam A Framenark for an Isamic Philoshophy of Education, terj. Haidar Baqir. Bandung : Mizan, 1994.

D epartemen Pendidikan Nasional. KunikulumKTSP untuk Mapd Pendidikan Agama Islamd

SD. Jakarta: Departemen Pendidikan Nasional, 2006.

D epartemen Pendidikan Nasional. KurikulumKTSP untuk Mapd Pendidkan Kenarganeggraan di SD. Jakarta, 2006.

${ }^{41}$ O bservasi tim peneliti pada saat mendampingi guru mengujicobakan produk penelitian ini.

${ }^{42} \mathrm{D}$ alam pembelajaran modern, penggunaan media yang lebih menarik sangat membantu daya tarik tersendiri di samping memudahkan siswa memahai materi yang disampaikan oleh guru. 
D epartemen Pendidikan Nasional. Pendidikan Kenarganeggraan untuk SD (Buku I). Jakarta: D epartemen Pendidikan, 2006.

Fogarty, Robin. HowTo IntegateTheCuriala. Palatine: Illinois, 1991.

Nata, A budin. H. Penikiran Para Tdkoh Penddkan Idam Jakarta: UIN Syarif Hidayatullah, 2000.

Nur, Mohamad. Modł-modd Penbdajaran Surabaya : Unesa University Press, 2005.

Sudikin, Basrowi. Metode Penditian Kualitatif Pesspktif Mikra Jakarta: Insan Cendekia, 2002.

Yani, Muhammad Turhan. Dialektika Septar Pendidkan Surabaya: Unesa University Press, 2006. 